Юрій Свгенович Репіло (доктор військових наук, професор) Андрій Іванович Мостовий ${ }^{2}$

${ }^{1}$ Національний університет оборони України імені Івана Черняховського, Київ, Україна

${ }^{2}$ Національна академія Державної прикордонної служби Украӥни ім. Б. Хмельницького, Украйна

\title{
АНАЛІЗ ПРИКОРДОННОЇ БЕЗПЕКИ НА СХОДІ УКРАЇНИ ТА ОСОБЛИВОСТІ ІЇ ЗАБЕЗПЕЧЕННЯ СИЛАМИ ТА ЗАСОБАМИ ПРИКОРДОННИХ ЗАГОНІВ В РАЙОНІ ОПЕРАЦІЇ ОБ'ЄДНАНИХ СИЛ
}

У науковій статті узагальнено основні загрози національній безпеці, надано характеристику операції Об'єднаних сил на сході Украӥни, прикордонній безпеці та розкрито особливості застосування сил та засобів прикордонних загонів Державної прикордонної служби Украӥни в районі проведення зазначеної операції. Узагальнено комплекс заходів, щзо проводяться прикордонними загонами Державної прикордонної служби України для протидії загрозам і викликам, щзо негативно впливають на стан прикордонної безпеки. Надано класифікацію кодів ускладнення обстановки та систематизовано за важливістю значень изифрові індекси кожного типу можливих небезпек на діляниі відповідальності прикордонних загонів.

Встановлено, що в умовах ускладнення обстановки функиіонування прикордонних загонів в районі операції об'єднаних сил буде характеризуватись «зеленим» інформаційним кодом за рівнями ускладнення від «4» до «1», де: «4»-для реагування достатньо чергових сил та засобів прикордонного загону; «3»потребує застосування резерву першої черги та чергових сил та засобів сусідніх прикордонних загонів; «2»- потребує застосування резерву другої черги та резерву периої черги сусідніх прикордонних загонів; «1»- потребує застосування усіх наявних ресурсів, а також резервів сусідніх прикордонних загонів.

Ключові слова: прикордонна безпека; операція Об'єднаних сил; прикордонний загін; обстановка.

\section{Ветуп}

Державна прикордонна служба (далі-ДПС) України у взаємодії 3 іншими суб'єктами забезпечення прикордонної безпеки, повноваження яких пов'язані 3 охороною та захистом державного кордону, продовжує здійснювати комплекс заходів щодо протидії усім загрозам державного суверенітету і територіальній цілісності України. Однак, трансформаційні процеси, що відбуваються в сучасному світі, зумовили появу нових загроз прикордонній безпеці України. Тому, вирішення проблемних питань щодо забезпечення прикордонної безпеки набуває дедалі більшої актуальності в загальному процесі пов'язаного 3 агресивною політикою Російської Федерації (далі-РФ) проти України, посиленням впливу проросійських центрів сил, наявністю сепаратистських настроїв у прикордонних регіонах України та Росії, що мають наміри переглянути належність частини державної території України та інше.

Постановка проблеми. Пріоритетність та масштабність завдань ДПС України щодо підвищення ефективності їі діяльності і адекватної протидії загрозам прикордонній безпеці зумовлюють необхідність впровадження новітніх технологій охорони, покращення координації та взаємодії між суб'єктами забезпечення прикордонної безпеки та інші заходів, зокрема, удосконалення способів та методів застосування сил та засобів прикордонних загонів для забезпечення прикордонної безпеки в районі операції об'єднаних сил (далі-ООС) на сході України [1]. У даному контексті, дослідження прикордонної безпеки на сході України та особливості іï забезпечення силами та засобами прикордонних загонів в районі ООС є актуальним на національному, регіональному та міжнародному безпекових аспектах.

Аналіз остатніх досліджень і публікацій. Результати аналізу наукових праць свідчать, що питання щодо застосування сил та засобів прикордонних загонів в районі проведення ООС досліджувались у незначній кількості наукових праць. Розгляду науково-теоретичних та прикладних аспектів у сфері захисту та охорони державного кордону України присвячені дослідження [2-7]: $\quad$ В. О. Назаренка, О. А. Біньковського, Ю. Б. Івашкова, $\begin{array}{ll}\text { I. С. Катеринчука, } & \text { В. А. Кириленка, }\end{array}$ Д. А. Купрієнка, М. М. Литвина, А. В. Махнюка, А. Б. Мисика, В. М. Серватюка, та ін. Водночас, попри значний інтерес до означеної проблематики, комплексних досліджень питань забезпечення прикордонної безпеки України силами та засобами прикордонних загонів в районі проведення ООС практично відсутні, що обумовлює необхідність у проведенні подальших наукових досліджень.

Метою статті $\epsilon$ аналіз прикордонної безпеки на сході України та особливості її забезпечення силами та засобами прикордонних загонів в районі ООС. 


\section{Виклад основного матеріалу дослідження}

Основними загрозами національної безпеки на сході України $є[1 ; 8-10]$ : військова агресія з боку РФ, участь регулярних військ, російських військових радників, інструкторів та найманців у бойових діях в окремих районах Донецької та Луганської областей; терористична загроза: переміщення на територію України членів терористичних угруповань, підрозділів сил спеціальних операцій збройних сил РФ, зброї, боєприпасів, засобів диверсій та терору, фінансування тероризму та екстремістських рухів в Україні з території окремих районів Донецької та Луганської областей, а також 3 території РФ; інформаційна загроза, пов'язана 3 переміщенням 3 РФ пропагандистських матеріалів антиукраїнського характеру та радикально налаштованих осіб, які намагаються дестабілізувати соціально-політичну обстановку та дискредитувати діяльність української влади; організована транскордонна злочинність у сферах незаконного переміщення осіб, наркотичних та психотропних речовин; незаконна міграція громадян країн Близького та Середнього сходу, Південно-східної Азії до країн Європейського союзу, як на організованих каналах незаконної міграції, так і на легальних каналах виїзду в Україну;торгівля людьми, як до Туреччини, Греції, Кіпру та країн арабського світу через пункти пропуску для авіаційного сполучення в Україні, так i до РФ залізничним та автомобільним сполученням; активна діяльністю протиправних груп 3 незаконного переміщення товарів, стійкою пособницькою базою серед місцевих жителів.

3 метою протидії загрозам національній безпеці, стабілізацію ситуації, відновлення територіальної цілісності України та соціальне відродження східного регіону України 30 квітня 2018 року на окремих територіях Донецької та Луганської областей України розпочалась ООС [9].

Особливістю ООС на сході України є те, що Рішення про початок та завершення ООС приймає президент України, тоді як безпосереднє керівництво операцією та прийняття усіх рішень в рамках операції покладається на командувача Об'єднаного оперативного штабу Збройних сил (далі-3C). Таким чином, повноваження 3 керування військовими i правоохоронними підрозділами перейшло до Генерального штабу 3С України. Командувач об'єднаних сил керує всіма військовими та правоохоронними підрозділами залученими до виконання із оборони та відсічі збройної російської агресії на сході України.

3 початком ООС вводяться поняття «райони бойових дій» та «зони безпеки». Зокрема, під «районами бойових дій» маються на увазі території, охоплені бойовими діями уздовж лінії зіткнення, де відповідні військові та правоохоронні підрозділи виконують завдання із недопущення прориву ворога далі на територію України. Водночас «зони безпеки» тепер будуть розташовані на контрольованих Україною територіях поруч з лінією розмежування на сході України, a їх межі визначатиме начальник Генштабу за поданням керівника об'єднаних сил. Крім того, в «зоні безпеки» можуть створюватися «райони обмеженого доступу» та «райони забороненого доступу», куди можна потрапити лише за спеціальними дозволами залежно від рівня допуску. Крім того, в «зонах безпеки» можуть вводитися різні режими перебування: зелений (без обмежень перебування та переміщення), жовтий (перебування та переміщення дозволене за наявності документів, допускається особистий огляд громадян, їхнього транспорту та речей) та червоний (перебування частково обмежене чи заборонене взагалі, пропуск громадян та посадових осіб дозволяється лише за наявності пропуску, транспорт та громадяни на окремі ділянки взагалі не допускаються).

3 метою забезпечення безпекового простору та його режиму в районі проведення ООС Україна реалізується прикордонна політика у сфері захисту й охорони державного кордону, суверенних прав у виключній (морській) економічній зоні та континентального шельфу у [8].

Основними завданнями прикордонної політики України є: створення умов для забезпечення суверенітету і територіальної цілісності України, іiі прикордонної безпеки; удосконалення міжнародно-правового оформлення державного кордону; запобігання воєнній небезпеці, кризам i конфліктам у прикордонному просторі України; адекватне реагування на зміни рівня транскордонного співробітництва із суміжними державами» [10].

Основною складовою національної безпеки України $\epsilon$ прикордонна безпека, яка характеризується ступенем захищеності територіальної цілісності та суверенітету держави, усіх сфер громадського життя і людської діяльності, прав та свобод громадян у прикордонному просторі, у зв'язку з чим досягається своєчасне виявлення, запобігання, нейтралізація реальних (потенційних) внутрішніх i зовнішніх загроз та забезпечується сталий розвиток прикордонних територій, транспарентність державного кордону для здійснення прикордонної діяльності та подорожування осіб [7;9]. Така характеристика прикордонної безпеки дозволяє класифікувати іiі на три групи.

До першої групи слід віднести загрози, більшою мірою, впливають на становище держави в міжнародному співтоваристві. Вони не представляють серйозної небезпеки, але сильна країна не має права дозволяти навіть незначні правопорушення на своєму кордоні.

Друга група загроз являють собою правопорушення, здатні дестабілізувати обстановку у прикордонні і завдати їй певний матеріальний збиток.

Третя група загроз здатна не тільки загострити обстановку на кордоні і спричинити за собою значні матеріальні збитки, але i вплинути на безпеку країни в цілому.

Результати аналізу реальних та потенційних 
загроз в районі проведення ООС свідчать про такі сталі тенденції, як:

довготривала агресія 3 боку РФ та контрольованих нею тимчасово окупованих окремих районів Луганської та Донецької областей;

продовжуються спроби ворожих спецслужб утворити в Україні низку незаконних організацій для посягання на іiі територіальну цілісність і державний суверенітет, дестабілізації суспільнополітичної та соціально-економічної обстановки.

незаконне переміщення через державний кордон України зброї, а також економічної контрабанди;

діяльність транснаціональних і транскордонних злочинних груп набуває все більшої організованості. При цьому найбільшу актуальність мають: неконтрольована міграція, торгівля людьми та їх органами, незаконний обіг зброї, боєприпасів i інших засобів терору, наркотичних засобів та їх прекурсорів, контрафактних товарів тощо.

3 метою протидії загрозам i викликам, що негативно впливають на стан прикордонної безпеки України ДПС через підпорядковані прикордонні загони здійснює комплекс заходів, а саме:

участь в обороні лінії зіткнення, відсічі збройної агресії на підконтрольну українській владі територію;

здійснення в установленому порядку пропуску осіб, транспортних засобів, вантажів через лінію зіткнення у встановлених контрольних пунктах в'їзду-виїзду (далі-КПВВ) та здійснення прикордонного контролю в ППр;

протидія протиправній діяльності в смузі безпеки та іншим правопорушенням законодавства України з прикордонних питань;

проведення заходів протидії диверсійнорозвідувальним силам противника, незаконним збройним формуванням, терористичним групам, які намагаються діяти через державний кордон;

посилення охорони визначених важливих об'єктів та комунікацій;

ведення оперативно-розшукової діяльності в інтересах забезпечення захисту суверенітету згідно із Законом України;

виконання доручень правоохоронних органів щодо осіб, які перетинають лінію зіткнення;

координація діяльності контрольних органів, що здійснюють різні види контролю при перетинанні лінії зіткнення або беруть участь у забезпеченні прикордонного режиму і режиму в КПВВ;

підтримання високого рівня боєготовності, організованості, статутного порядку та дисципліни.

Військовослужбовцям прикордонних загонів ДПС в районі проведення ООС законодавством України надано спеціальні повноваження:

перевіряти у громадян i посадових осіб документи, що посвідчують особу, а в разі відсутності документів - затримувати їх для встановлення особи;

застосовувати в разі крайньої необхідності зброю спеціальні засоби до осіб, які вчинили або вчиняют правопорушення чи інші дії, що перешкоджають виконанню законних вимог осіб, залучених до виконання заходів із забезпечення національної безпеки і оборони, відсічі та стримування збройної агресії РФ в Донецькій та Луганській областях, або діï, пов'язані 3 несанкціонованою спробою проникнення в район здійснення зазначених заходів;

затримувати i доставляти осіб до органів Національної поліції України;

здійснювати особистий огляд громадян, їхніх речей, транспортних засобів та речей, які вони перевозять;

тимчасово обмежувати або забороняти рух транспортних засобів i пішоходів на вулицях та дорогах, не допускати транспортних засобів, громадян на окремі ділянки місцевості та об'єкти, виводити громадян 3 окремих ділянок місцевості та об'єктів, відбуксировувати транспортні засоби;

заходити (проникати) в житлові та інші приміщення, на земельні ділянки, що належать громадянам, на територію та в приміщення підприємств, установ і організацій, перевіряти транспортні засоби;

використовувати із службовою метою засоби зв'язку i транспортні засоби, в тому числі спеціальні, що належать громадянам (за їхньою згодою), підприємствам, установам та організаціям, крім транспортних засобів дипломатичних, консульських та інших представництв іноземних держав та міжнародних організацій.

Роль прикордонних загонів в ООС по відношенню до завдань функціонування та процесу досягнення ними встановленої ефективності [11] полягає у створенні в контрольованих прикордонних районах належних умов, які б унеможливлювали реалізацію загроз та поширення їх наслідків углиб держави.

Особливості діяльності прикордонних загонів, ix місце, можливі форми і способи застосування визначаються положенням сторін, напрямками дій противника, завданнями ООС, динамікою обстановки тощо.

Діяльність прикордонних загонів в ООС характеризується специфічним спрямуванням, а саме: відбиття збройного вторгнення; присікання озброєних та інших провокацій; захист ділянки відповідальності прикордонного загону від злочинних посягань; недопущення перетину лінії розмежування поза КПВВ; пошук, виявлення та затримання правопорушників; підтримка режиму, прикордонного режиму, режиму в КПВВ, режиму особливого періоду тощо. Крім того, прикордонні загоні проводять комплекс заходів 3 викриття підготовки противника до агресії, виявлення диверсійно-розвідувальних груп, інших підрозділів спеціального призначення противника, ознак нарощування його агентурної та диверсійнорозвідувальної діяльності.

Особливості застосування прикордонних загонів в районі проведення ООС можна проаналізувати на основі інформаційних кодів, класифікація яких за окремими небезпеками представлена у таблиці 1 [12]. 
Таблиця

Класифікація колірного коду ускладнення обстановки за окремими небезпеками на ділянці прикордонних загонів в районі ООС

\begin{tabular}{|c|c|c|}
\hline $\begin{array}{c}\text { Значення колірного } \\
\text { коду та типу } \\
\text { небезпек }\end{array}$ & $\begin{array}{c}\text { Основні реальні та потенційні загрози } \\
\text { прикордонної безпеки в районі ООС }\end{array}$ & $\begin{array}{c}\text { Основні завдання прикордонних загонів } \\
\text { з протидії реальним та потенційним загрозам в } \\
\text { районі ООС }\end{array}$ \\
\hline «червоний» & \multirow[b]{2}{*}{ 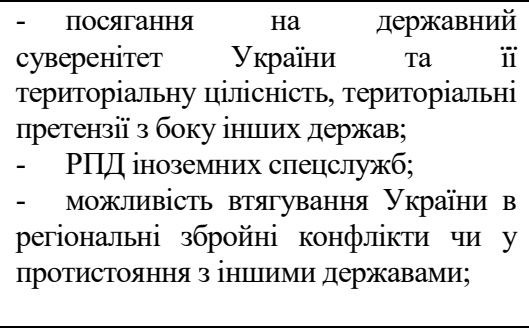 } & - здійснює ОДК на суші, морі, річках, озерах та \\
\hline 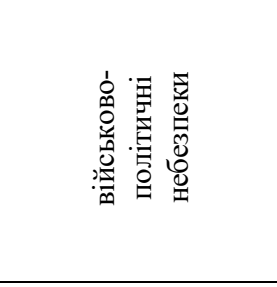 & & $\begin{array}{l}\text { інших водоймах, припиняє спроби незаконної } \\
\text { зміни проходження державного кордону України; } \\
\text { - у взаємодії } 3 \text { підрозділами військових } \\
\text { формувань України, правоохоронних органів } \\
\text { припиняє збройні конфлікти та провокації на } \\
\text { кордоні, бере участь у відбитті вторгнення або } \\
\text { нападу на територію України збройних сил іншої } \\
\text { держави або груп держав тощо. }\end{array}$ \\
\hline «білий»" & \multirow[b]{2}{*}{$\begin{array}{l}\text { - можливість незаконного ввезення } \\
\text { в країну зброї, боєприпасів, } \\
\text { вибухових речовин і засобів масового } \\
\text { ураження, радіоактивних і } \\
\text { наркотичних засобів через пункти } \\
\text { пропуску (КПВВ); } \\
\text { - нелегальна міграція на шляхах } \\
\text { міжнародного сполучення; } \\
\end{array}$} & \multirow[b]{2}{*}{$\begin{array}{l}\text { - здійснює контроль за дотриманням режиму } \\
\text { державного кордону та режиму в КПВВ; } \\
\text { - здійснює виявлення в КПВВ осіб, які } \\
\text { переховуються від органів досудового } \\
\text { розслідування, слідчого судді та суду, ухиляються } \\
\text { від відбуття кримінальних покарань, та виконання } \\
\text { в установленому порядку інших доручень } \\
\text { уповноважених державних органів тощо. }\end{array}$} \\
\hline 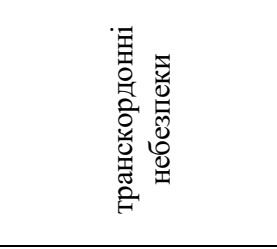 & & \\
\hline «зелений» & \multirow[b]{2}{*}{$\begin{array}{l}\text { - } \\
\text { вожливість незаконного ввезення } \\
\text { в країну зброї, боєприпасів, } \\
\text { вибухових речовин і засобів масового } \\
\text { ураження, } \quad \text { радіоактивних } \\
\text { наркотичних засобів поза ППр; } \\
\text { - нелегальна міграція; } \\
\text { - } \text { незавершеність договірно- } \\
\text { правового оформлення ДК; }\end{array}$} & - здійснює контроль за дотриманням режиму \\
\hline 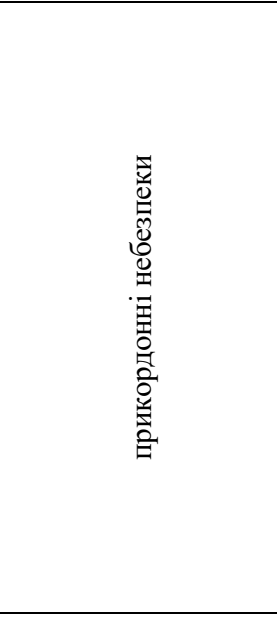 & & $\begin{array}{l}\text { держ. кордону та прикордонного режиму в } \\
\text { прикордонній смузі та контрольованому } \\
\text { прикордонному районі; } \\
\text { - бере участь у проведенні прикордонних } \\
\text { (спільних) операцій, здійснює спеціальні дії щодо } \\
\text { пошуку порушників законодавства України } \\
\text { прикордонних питань; } \\
\text { - на основі аналізу ризиків у сфері прикордонної } \\
\text { безпеки здійснює протидію нелегальній міграції, } \\
\text { торгівлі людьми, незаконному переміщенню осіб, } \\
\text { зброї, наркотичних засобів, психотропних речовин } \\
\text { і прекурсорів, боєприпасів, вибухових, отруйних, } \\
\text { радіоактивних речовин та інших предметів, } \\
\text { заборонених до переміщення через держ. кордон } \\
\text { та до тимчасово окупованої території і з неї, } \\
\text { порушенням порядку в’їзду на тимчасово } \\
\text { окуповану територію України та виїзду з неї тощо. }\end{array}$ \\
\hline
\end{tabular}

В цифровому індексі кожного типу небезпек узагальнюється ступінь важливості значення події чи загрози ускладнення обстановки на ділянці відповідальності прикордонних загонів (див. табл. 2).
Динаміка і масштаби ускладнення обстановки можуть поєднувати різні типи небезпек, тому цифровий індекс ступеня найскладнішого із них буде обумовлювати загальний інформаційний код.

Таблиця 2

Класифікація цифрових індексів ступеня небезпек на ділянці прикордонних загонів в районі ООС

\begin{tabular}{|c|c|c|}
\hline $\begin{array}{c}\text { Цифровий } \\
\text { індекс }\end{array}$ & Вагове значення & Короткий опис небезпек \\
\hline I & катастрофічне & $\begin{array}{l}\text { - реальна загроза життю (загибель); } \\
\text { - безпека суспільства і держави під загрозою; } \\
\text { - неможливість забезпечити безпеки діяльності; } \\
\text { - повне підпадання підрозділу під вплив небезпечних чинників; } \\
\text { - суцільне знищення (втрата) засобів, пунктів, об'єктів та систем в зоні } \\
\text { небезпеки; } \\
\text { - неможливість подальших дій, функціонування чи застосування; } \\
\text { - потреба в повному переорієнтуванні діяльності; }\end{array}$ \\
\hline II & критичне & $\begin{array}{l}\text { - потенційна загроза життю і здоров’ю (серйозні травми, захворювання); } \\
\text { - суттєвий підрив інтересів суспільства і держави; } \\
\text { - значне підпадання підрозділу під вплив небезпечних чинників; } \\
\text { - значне порушення умов життєдіяльності; } \\
\text { - значне ушкодження засобів, пунктів, об'єктів та систем в зоні небезпеки; } \\
\text { - для здійснення подальших дій, функціонування чи застосування потрібні } \\
\text { значні ресурси та зусилля тощо; }\end{array}$ \\
\hline
\end{tabular}




\begin{tabular}{|c|c|c|}
\hline $\begin{array}{c}\text { Цифровий } \\
\text { індекс }\end{array}$ & Вагове значення & Короткий опис небезпек \\
\hline III & граничне & $\begin{array}{l}\text { - суттєва загроза здоров’ю (травми, захворювання); } \\
\text { - загроза окремим інтересам суспільства і держави; } \\
\text { - суттєве підпадання підрозділу під вплив небезпечних чинників; } \\
\text { - певні порушення умов життєдіяльності; } \\
\text { - суттєве ушкодження засобів, пунктів, об'єктів та систем в зоні небезпеки; } \\
\text { - для здійснення подальших дій, функціонування чи застосування потрібні певні } \\
\text { ресурси та зусилля тощо; }\end{array}$ \\
\hline IV & незначне & $\begin{array}{l}\text { - незначна загроза здоров’ю; } \\
\text { - часткове підпадання підрозділу під вплив небезпечних чинників; } \\
\text { - умови життдіяльності дозволяють безпечно виконувати покладені завдання; } \\
\text { - часткове ушкодження засобів, пунктів, об’єктів та систем в зоні небезпеки; } \\
\text { - для здійснення подальших дій, функціонування чи застосування достатньо } \\
\text { наявних ресурсів; } \\
\text { - загалом немає потреби в переорієнтуванні діяльності, зосередження зусиль на } \\
\text { інших напрямках (заходах) та інше. }\end{array}$ \\
\hline
\end{tabular}

\section{Висновки й перспективи подальших досліджень}

Таким чином, на основі аналізу прикордонної безпеки на сході України узагальнено значущі чинники, що впливають на неї та надано загальну характеристику ООС.

Узагальнено завдання та розкрито основні аспекти і особливості застосування сил та засобів прикордонних загонів ДПС України для забезпечення прикордонної безпеки в районі проведення ООС.

Встановлено, що функціонування прикордонних загонів в районі ООС в умовах ускладнення обстановки буде характеризуватись «зеленим» інформаційним кодом і відповідними цифровими

\section{Лimepamypa}

1. Аналітична доповідь до Щорічного Послання Президента України до Верховної Ради України «Про внутрішне та зовнішне становище України в 2018 році» : НІСД. Київ, 2018. 688 с. 2. Назаренко В. О. Безпека європейських кордонів:український вимір : Науковий вісник Державної прикордонної служби. № 1, 2008.С. 3-8. 3. Біньковський О. А. Сучасні підходи до розвитку системи пропуску через державний кордон осіб i транспортних засобів / Актуальні питання прикордонної безпеки. Сучасний стан та перспективи розвитку. 2011. № 2. С. 37-43. 4. Кириленко В. А. Загрози національної безпеки держави в прикордонній сфері та їх інформаційні ознаки : зб. наук. пр. № 43. Хмельницький : НА ДПСУ, 2008. С. 616. 5. Мисик А. Б., Купрієнко Д. А. Модель системи підтримки прийняття рішень на проведення спільних (міжнародних) прикордонних операцій : зб. наук. пр. Хмельницький: НАДПСУ, 2016. № 24, ч. І.С. 12-26. б. Литвин М. М. Прикордонна безпека України: етапи становлення, проблеми i перспективи // Національна безпека: український вимір: щокв. наук. зб. / Рада нац. безпеки і оборони України, Ін-т пробл. нац. безпеки; редкол.: Горбулін В.П. (голов. ред.)[та ін.].К., 2008. Вип. 1-2 (20-21).41-46 с. 7. Серватюк В. М. індексами - від чотирьох до одного, який визначає необхідність застосування наступних: «4»-для реагування достатньо чергових сил та засобів прикордонного загону; «3»-рівень ускладнення обстановки потребує застосування резерву першої черги та чергових сил та засобів сусідніх прикордонних загонів; «2»-рівень ускладнення обстановки потребує застосування резерву другої черги та резерву першої черги сусідніх прикордонних загонів; «1»-суттєвий рівень ускладнення обстановки, який потребує застосування усіх наявних ресурсів підрозділу, а також резервів прикордонного загону та сусідніх 3 ним загонами.

Основні підходи до оцінки регіональної стабільності у прикордонному просторі : зб. наук. пр. № 12, ч. 2. Хмельницький: НА ПВУ, 2000. С. 28-36. 8. Про національну безпеку України: Закон України від 21.06.2018 № 2469-VIII. Відомості Верховної Ради України. Київ, 2018. № 31. Ст. 241. 9. Концептуальні засади розвитку системи забезпечення національної безпеки України: аналіт. доп URL: http://www.niss.gov.ua/content/articles/files/nac_bezp182c8.p df (дата звернення: 30.03.2020р.). 10. Ставицький О. М., Мостовий А. І. Оцінка стану прикордонної безпеки за визначеними індикаторами : зб. наук. пр. Хмельницький : НА ДПСУ, 2018. № 1 (75) С. 231-242. 11. Майстренко О.В., Репіло Ю.Є., Демидко Д.Л. Пропозиції по уточненню понятійного апарату дослідження явищ та процесів: військовий аспект: Сучасні інформаційні технології у сфері безпеки та оборони, №3(24)/2015, С. 161-165. 12. Кириленко В. А., Городнов В. П., Каратаєв Р. Г. Загрози національної безпеки держави в прикордонній сфері та їх інформаційні ознаки : зб. наук. пр. № 43. Балашов В. О. Хмельницький : НА ДПСУ, 2008. С. 616.

\title{
АНАЛИЗ ПОГРАНИЧНОЙ БЕЗОПАСНОСТИ НА ВОСТОКЕ УКРАИНЫ И ОСОБЕННОСТИ ЕЕ ОБЕСПЕЧЕНИЯ СИЛАМИ И СРЕДСТВАМИ ПОГРАНИЧНЫХ ОТРЯДОВ В РАЙОНЕ ПРОВЕДЕНИЯ ОПЕРАЦИИ ОБЪЕДИНЕННЫХ СИЛ
}

\author{
Юрий Евгеньевич Репило (доктор военных наук, профессор) $)^{1}$ \\ Андрей Иванович Мостовый ${ }^{2}$
}

\footnotetext{
${ }^{1}$ Национальный университет обороны Украины имени Ивана Черняховского, Киев, Украина ${ }^{2}$ Национальная академия Государственной пограничной службы Украины им. Б. Хмельницкого, Украина Modern Information Technologies in the Sphere of Security and Defence № 1(37)/2020 ISSNN2311-7249(Print)/ISSNN2410-7336(Onfine) 189
} 
В научной статье обобщены основные угрозы нащиональной безопасности, подана характеристика операции Объединенных сил на востоке Украины, пограничной безопасности и раскрыты особенности применения сил и средств пограничных отрядов Государственной пограничной службы Украины в районе проведения указанной операчии. Обобщен комплекс средств, которые проводятся пограничными отрядами Государственной пограничной служббы Украиньл для противодействия угрозам и вызовам, что негативно влияют на состояние пограничной безопасности. Дана классификащия кодов обострения обстановки и систематизированы по важности значений цฺифровые индексы каждого типа возможных угроз на участке ответственности пограничных отрядов.

Установлено, что в условиях обострения обстановки робота пограничных отрядов в районе проведения операции Объединенных сил будет выражаться «зеленым» информационным кодом по уровням осложнения от «4» до «1», где: «4»-для реагирования достаточно дежурных сил и средств пограничного отряда; «3»-требует применения резерва первой очереди и дежурных сил и средств соседних пограничных отрядов; "2»-требует применения резерва второй очереди и резерва первой очереди соседних пограничных отрядов; “1»-требует применения всех имеющихся ресурсов, а также резервов соседних пограничных отрядов.

Ключовые слова: пограничная безопасность; операция Объединенных сил; пограничный отряд; обстановка.

\title{
BORDER SECURITY ANALYSIS IN EASTERN UKRAINE AND PECULIARITIES OF PROVIDING IT BY FORCES AND FACILITIES OF BORDER GUARD DETACHMENTS IN THE AREA OF JOINT FORCES OPERATION
}

\author{
Iurii Repilo (Doctor of military sciences, Professor) ${ }^{1}$ \\ Andrii Mostovyi ${ }^{2}$ \\ ${ }^{1}$ National Defence University of Ukraine named after Ivan Cherniakhovsky, Kyiv, Ukraine \\ ${ }^{2}$ National Academy of State Border Guard Service of Ukraine named after B. Khmelnytsky, Ukraine
}

The scientific article summarizes the main threats to national security, describes the operation of the Joint Forces in eastern Ukraine, border security and reveals the peculiarities of using forces and facilities of border guard detachments of the State Border Guard Service of Ukraine in the area of the aforementioned operation. The complex of actions carried out by border guard detachments of the State Border Guard Service of Ukraine to counter threats and challenges that negatively affect the state of border security was summarized. The classification of codes for the situational aggravations is given and the indexes of each type of possible danger in the area of responsibility of the border guard detachments are organized according to the importance of values.

It is established that in conditions of aggravation of the situation for functioning of the border guard detachments in the area of the Joint Forces operation will be characterized by a "green" information code at the levels of aggravation from " 4 " to " 1 ", where: "4" - to react it is enough regular forces and facilities of a border guard detachment; "3" - it is necessary to deploy the Ready Reserve and the standby forces of neighbouring border guard detachments; "2" - it is necessary to deploy the Standby Reserve and the Standby Reserve of neighbouring border guard detachments; "1" - it is necessary to deploy all available resources, as well as the reserves of neighbouring border guard detachments.

Keywords: border security; Joint Forces operation; border guard detachment; situation.

\section{References}

1. Analitychna dopovid do Shchorichnoho Poslannia Prezydenta Ukrainy do Verkhovnoi Rady Ukrainy «Pro vnutrishnie ta zovnishnie stanovyshche Ukrainy v 2018 rotsi» : NISD. Kyiv, 2018. 688 s. 2. Nazarenko V. O. Bezpeka yevropeiskykh kordoniv:ukrainskyi vymir : Naukovyi visnyk Derzhavnoi prykordonnoi sluzhby. № 1, 2008.S. 3-8. 3. Binkovskyi O. A. Suchasni pidkhody do rozvytku systemy propusku cherez derzhavnyi kordon osib i transportnykh zasobiv / Aktualni pytannia prykordonnoi bezpeky. Suchasnyi stan ta perspektyvy rozvytku. 2011. № 2. S. 37-43. 4. Kyrylenko V. A. Zahrozy natsionalnoi bezpeky derzhavy $\mathrm{v}$ prykordonnii sferi ta yikh informatsiini oznaky : zb. nauk. pr. № 43. Khmelnytskyi : NA DPSU, 2008. S. 616. 5. Mysyk A. B., Kupriienko D. A. Model systemy pidtrymky pryiniattia rishen na provedennia spilnykh (mizhnarodnykh) prykordonnykh operatsii : zb. nauk. pr. Khmelnytskyi: NADPSU, 2016. № 24, ch. I.S. 12-26. 6. Lytvyn M. M. Prykordonna bezpeka Ukrainy: etapy stanovlennia, problemy i perspektyvy // Natsionalna bezpeka: ukrainskyi vymir: shchokv. nauk. zb. / Rada nats. bezpeky i oborony Ukrainy, In-t probl. nats. bezpeky; redkol.: Horbulin V.P. (holov. red.)[ta in.].K., 2008. Vyp. 1-2 (20-21).41-46 s.
7. Servatiuk V. M. Osnovni pidkhody do otsinky rehionalnoi stabilnosti u prykordonnomu prostori : zb. nauk. pr. № 12, ch. 2. Khmelnytskyi: NA PVU, 2000. S. 28-36. 8. Pro natsionalnu bezpeku Ukrainy : Zakon Ukrainy vid 21.06.2018 № 2469-VIII. Vidomosti Verkhovnoi Rady Ukrainy. Kyiv, 2018. № 31. St. 241. 9. Kontseptualni zasady rozvytku systemy zabezpechennia natsionalnoi bezpeky Ukrainy : analit. dop URL: http://www.niss.gov.ua/content/articles/files/nac bezp182c8.pdf 10. Stavytskyi O. M., Mostovyi A. I. Otsinka stanu prykordonnoi bezpeky za vyznachenymy indykatoramy : zb. nauk. pr. Khmelnytskyi : NA DPSU, 2018. № 1 (75) S. 231242. 11. Maistrenko O.V., Repilo I.Y, Demydko D.L. Events and processes research conceptual structure refinement proposals: military aspect: Modern Information Technologies in the Sphere of Security and Defence, , №3(24)/2015, P. 161-165. 12. Kyrylenko V. A., Horodnov V. P., Karataiev R. H. Zahrozy natsionalnoi bezpeky derzhavy $\mathrm{v}$ prykordonnii sferi ta yikh informatsiini oznaky : zb. nauk. pr. № 43. Balashov V. O. Khmelnytskyi : NA DPSU, 2008. S. 616. 